\title{
Detection Technology of Metal Elements in Crude Oil and Prospect of Utilization of Metal Resources
}

\author{
Bai Fengyou \\ Daqing Oilfield Exploration and Development Research Institute, Daqing, China
}

Email address:

baify@petrochina.com.cn

\section{To cite this article:}

Bai Fengyou. Detection Technology of Metal Elements in Crude Oil and Prospect of Utilization of Metal Resources. Journal of Energy and Natural Resources. Vol. 7, No. 1, 2018, pp. 12-17. doi: 10.11648/j.jenr.20180701.12

Received: January 1, 2018; Accepted: February 5, 2018; Published: February 24, 2018

\begin{abstract}
There are many kinds of metals in crude oil. The rare metals are essential metals for the development of atomic energy, aviation and space, national defense construction, electronic computer, high point scientific instruments and so on. Although the resources of rare metals are abundant in China, but for a long time, china supplies $90 \%$ of the world's rare metals at a relatively low price, the reserves of rare metal resources are declining at an alarming rate. By 2020, only 6 of the 45 major minerals could meet the needs of China. Through the establishment of metal element detection technology in crude oil, the crude oil of Toutai Oil Field in China is determined, and there are rich rare metal elements in the crude oil. For example, the rare-earth metal content is 62.61 micrograms per kilogram, the rare light metals is 78.4 micrograms per kilogram, and the rare refractory metals is 290.47 micrograms per kilogram, etc. Although the research on the prospect of comprehensive utilization of rare metals in crude oil is late in China, the extraction of rare metals from crude oil has a broad prospect.
\end{abstract}

Keywords: Crude Oil, Metal, Detection Technology, Resource Utilization, Prospect

\section{Introduction}

Crude oil contains a variety of metal elements. Since Mexico has detected 12 trace elements from crude oil in 1922, [1], more than 50 kinds of metal elements have been detected from crude oil, including gold $(\mathrm{Au})$, silver $(\mathrm{Ag})$, ruthenium $(\mathrm{Ru})$, rhodium $(\mathrm{Rh})$ and palladium $(\mathrm{Pd})$, osmium $(\mathrm{Os})$, iridium (Ir), platinum (Pt), scandium ( $\mathrm{Sc})$, yttrium $(\mathrm{Y})$, lanthanum $(\mathrm{La})$, cerium $(\mathrm{Ce})$, praseodymium $(\mathrm{Pr})$, neodymium $(\mathrm{Nd})$, samarium $(\mathrm{Sm})$ and europium $(\mathrm{Eu})$, gadolinium $(\mathrm{Gd})$, terbium (Tb), dysprosium (Dy), holmium (Ho), erbium (Er), thulium (Tm), titanium (Ti), zirconium $(\mathrm{Zr})$, hafnium $(\mathrm{Hf})$, vanadium $(\mathrm{V})$, niobium $(\mathrm{Nb})$, tantalum (Ta), molybdenum (Mo), tungsten $(\mathrm{W})$, gallium $(\mathrm{Ga})$, indium (In), thallium (Tl), germanium $(\mathrm{Ge})$, rhenium (Re), selenium (Se), tellurium $(\mathrm{Te})$, ytterbium ( $\mathrm{Yb}$ ), lutetium (Lu), lithium (Li), beryllium (Be), rubidium $(\mathrm{Rb})$, cesium $(\mathrm{Cs})$ and so on. The content of metal elements in crude oil varies greatly in the world, for example, Kazakhstan's crude oil contains metal V 150 grams -280 grams per ton, Canada's crude oil contains metal V 250 grams and metal Ni 100 grams per ton, Venezuela's crude oil contains metal V 120 grams and metal Ni 150 grams per ton [2], Iran's crude oil contains metal V 110 grams per ton, Egypt's crude oil contains metal V 79 grams per ton [3].

The extraction of metal from crude oil has broad prospect. As early as the 1920s, scientists began to consider the problem of extracting metals from crude oil, and began to study it. At that time, experts believed that the era of "crude oil metallurgy" would come. When non-ferrous metal resources are on the verge of exhaustion, the time will come much faster. At present, the technology of extracting metals from crude oil is still in the research stage, therefore, it is more realistic to extract metals from the residuum of refineries. In these residuum, the content of $\mathrm{Na}, \mathrm{V}$ and $\mathrm{Fe}$ can be up to $10 \%$, the content of $\mathrm{Ni}$ is $6 \%, \mathrm{Mg}$ is $1.9 \%, \mathrm{Ca}$ is $1.2 \%$. Countries such as Sweden, Venezuela and Canada have studied the method of extracting metals from residuum, this method is capable of refining and extracting metals, "crude oil metallurgy" industry has been created. The United States, Japan, Germany, Canada, Russia and Western Europe have extracted metal V from raw oil, crude ash and waste catalyst, the total output of 2500 tons per year from the beginning of $80 \mathrm{~s}$, up to 3500 tons per year in the middle of $80 \mathrm{~s}$. In 1998 , the production reached a peak of 4300 tons. The United States is the largest country in the extraction of metal $\mathrm{V}$ from raw oil, crude ash and waste catalyst. 
For the determination of metal elements in crude oil and residual oil, it is first necessary to dissolve the metal in the crude oil and the residue into the water solution, then the metal element content in the aqueous solution is detected by a testing instrument. At present, the methods of crude oil sample treatment include dry ashing method, wet ashing method, microwave ashing method, organic solvent extraction, microwave digestion and so on. Dry ashing method, wet ashing method and microwave ashing method is not only complex and time-consuming to treat crude oil, but the low melting point metals such as $\mathrm{Li}, \mathrm{Be}, \mathrm{Rb}$ and $\mathrm{Cs}$ are highly volatile at high temperature, therefore, the ashing method is not suitable for sample processing and detection of these low melting metal elements. Organic solvent extraction can only effectively extract some metal elements such as $\mathrm{Fe}, \mathrm{Ni}$ and $\mathrm{V}$ in crude oil, and it is not ideal for many metal elements, it is often used in toxic organic solvents such as xylene and four hydrogenated sunflower, which can pollute the environment greatly. The microwave digestion method has the advantages of simple operation, fast processing speed and no loss of metal elements, it is the most ideal method for crude oil sample processing at present. However, because of the large difference in nature of the crude oil from different sources, the treatment conditions are different. The contents of metal elements in aqueous solution are mainly determined by spectrophotometry, potentiometric titration, polarography, atomic absorption spectrometry (AAS), inductively coupled plasma atomic emission spectrometry (ICP-AES), ICP-MS, etc. Spectrophotometry, potentiometric titration, polarography and AAS, these methods cannot be used for simultaneous detection of multiple elements, which is time-consuming and laborious, and there are some elements such as element interference and spectral interference. ICP-AES is suitable for the detection of constant metal elements, the sensitivity or detection limit for trace metal elements is not up to the index requirements. ICP-MS is the fastest growing inorganic trace detection technology in recent ten years, which has many advantages, such as multi-element detection, wide linear range, low detection limit and wide application range. Therefore, ICP-MS is the most commonly used detection method for metal element detection in aqueous solution.

In this paper, the detection technology of metal elements in crude oil is established by experiments. In addition, the utilization prospect of metal resources in crude oil is prospected through the detection of the content of metal elements in the crude oil samples.

\section{Detection Technology of Metal Elements in Crude Oil}

\subsection{Sample Treatment}

The key technology for sample treatment of crude oil is to dissolve all the metal elements into the solution. Therefore, the same crude oil samples are treated by microwave ashing apparatus and microwave digestion instrument, the effects of different treatment methods and different conditions on the treatment of crude oil are compared by different conditions, finally, the best treatment method of crude oil samples is determined. Test scheme for crude oil sample treatment, shown in table 1 .

Table 1. Test Scheme for Crude Oil Sample Treatment.

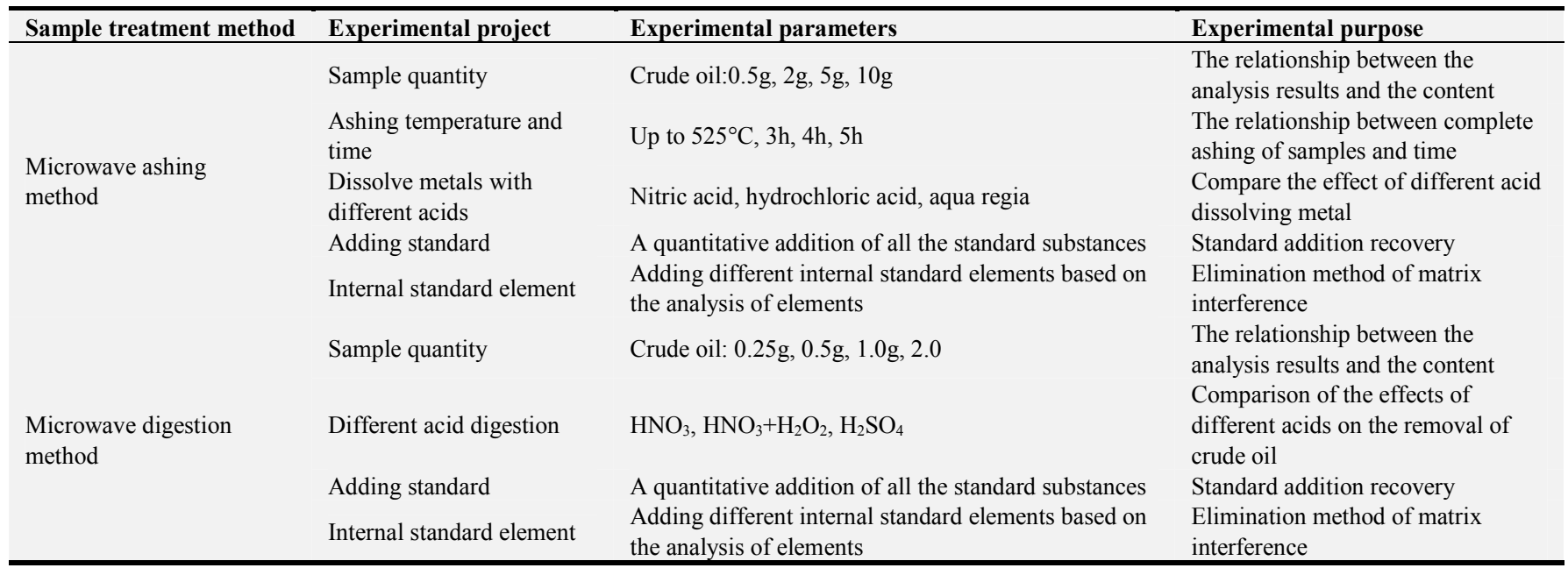

\subsection{Metal Element Detection}

After the metal elements in the crude oil samples are treated into aqueous solutions, the content of metal elements are detected by ICP-MS. The sample is atomized by the carrier gas into the atomization system and enters the axial channel of the plasma in the form of aerosols, being fully vaporized, dissociated, atomized and ionized in high temperature and inert gases, the converted charged positive ions are entered into the mass spectrometer by an ion acquisition system, the separation and quantitative analysis are carried out according to the mass number of the elements.

Because of the different properties of different metal elements, the preparation method and the preparation matrix of the standard solution are different. Therefore, in order to prepare the accurate concentration of the standard solution, 
the stability of metal elements in the solution is also considered, there is no mutual interference between metal elements, the metal elements of the similar properties are prepared together to form a mixed standard solution. The preparation method of mixed standard solution, shown in Table 2.

Table 2. Preparation Method of Mixed Standard Solution.

\begin{tabular}{ll}
\hline Metal element mixed standard solution & Prepared matrix \\
\hline $\mathrm{Cd}, \mathrm{Cr}, \mathrm{Cu}, \mathrm{Fe}, \mathrm{Mn}, \mathrm{Ni}, \mathrm{Pb}, \mathrm{V}, \mathrm{Zn}, \mathrm{Ag}, \mathrm{Al}, \mathrm{As}, \mathrm{Ba}, \mathrm{Be}, \mathrm{Bi}, \mathrm{Ca}, \mathrm{Cs}, \mathrm{Co}, \mathrm{K}, \mathrm{Li}, \mathrm{Mg}, \mathrm{Na}, \mathrm{Rb}, \mathrm{Se}, \mathrm{Sr}$ & $5 \% \mathrm{HNO}_{3}$ \\
$\mathrm{Sc}, \mathrm{Y}, \mathrm{La}, \mathrm{Ce}, \mathrm{Pr}, \mathrm{Nd}, \mathrm{Sm}, \mathrm{Eu}, \mathrm{Gd}, \mathrm{Tb}, \mathrm{Dy}, \mathrm{Ho}, \mathrm{Er}, \mathrm{Tm}, \mathrm{Yb}, \mathrm{Lu}$ & $5 \% \mathrm{HNO}_{3}$ \\
$\mathrm{Au}, \mathrm{Hf}, \mathrm{Ir}, \mathrm{Pd}, \mathrm{Pt}, \mathrm{Rh}, \mathrm{Ru}, \mathrm{Sb}, \mathrm{Sn}, \mathrm{Te}$ & $10 \% \mathrm{HCl}_{\text {and }} 1 \% \mathrm{HNO}_{3}$ \\
$\mathrm{~B}, \mathrm{Ge}, \mathrm{Mo}, \mathrm{Nb}, \mathrm{Si}, \mathrm{Ta}, \mathrm{Ti}, \mathrm{W}, \mathrm{Zr}$ & $\mathrm{H}_{2} \mathrm{O}$ and trace $\mathrm{HNO}_{3}$ and trace $\mathrm{HF}$ \\
\hline
\end{tabular}

\subsection{Experimental Results and Discussion}

\subsubsection{Experimental Results of Microwave Ashing Method}

The samples of different quality of crude oil are placed in different quartz crucibles, cover every quartz crucible with a lid, these quartz crucibles are put into the Microwave Ashing apparatus, different microwave power, different ashing temperature and different time length are selected for ashing, and add the standard material and the crude oil to be ashed together. Dissolve the metal elements in the ash with different acids, the content of metal elements are detected by ICP-MS after constant volume of dilute nitric acid. The detection results under optimal conditions, shown in Table 3, Table 4 and Table 5.

Table 3. Detection Result of Ashing Different Amount of Crude Oil and Parallel Sample.

\begin{tabular}{|c|c|c|c|c|c|c|c|c|c|c|c|c|}
\hline Sample & $\begin{array}{l}\text { Ni } 60 \\
(\mathrm{ppb})\end{array}$ & $\begin{array}{l}\text { Sb 121 } \\
\text { (ppb) }\end{array}$ & $\begin{array}{l}\text { Sr } 88 \\
(\mathrm{ppb})\end{array}$ & $\begin{array}{l}\text { V 51 } \\
\text { (ppb) }\end{array}$ & $\begin{array}{l}\text { Bi } 209 \\
\text { (ppb) }\end{array}$ & $\begin{array}{l}\text { In } 115 \\
\text { (ppb) }\end{array}$ & $\begin{array}{l}\text { Li } 7 \\
(p p b)\end{array}$ & $\begin{array}{l}\text { Au } 197 \\
\text { (ppb) }\end{array}$ & $\begin{array}{l}\text { La } 139 \\
\text { (ppb) }\end{array}$ & $\begin{array}{l}\text { Zr } 90 \\
(\mathrm{ppb})\end{array}$ & $\begin{array}{l}\text { Co } 59 \\
(\mathrm{ppb})\end{array}$ & $\begin{array}{l}\text { Cd 111 } \\
\text { (ppb) }\end{array}$ \\
\hline Sample, 5g & 22.208 & 0.997 & 78.767 & 4.918 & 0.680 & 0.687 & 8.461 & 0.029 & 1.854 & 5.797 & 3.555 & 0.379 \\
\hline Sample, $5 \mathrm{~g}$ & 19.561 & 4.301 & 78.689 & 3.507 & 0.392 & 0.156 & 9.767 & 0.134 & 1.776 & 2.951 & 2.781 & 0.206 \\
\hline The deviation & $6.34 \%$ & $62.36 \%$ & $0.05 \%$ & $16.75 \%$ & $26.87 \%$ & $62.99 \%$ & $7.16 \%$ & $64.42 \%$ & $2.15 \%$ & $32.53 \%$ & $12.22 \%$ & $29.57 \%$ \\
\hline Sample, $10 \mathrm{~g}$ & 29.301 & 0.468 & 95.510 & 7.207 & 0.097 & 0.041 & 8.730 & 0.007 & 2.485 & 0.808 & 4.578 & 0.088 \\
\hline Sample, $10 \mathrm{~g}$ & 38.383 & 3.155 & 100.772 & 14.092 & 3.213 & 0.958 & 12.669 & 6.340 & 2.493 & 2.491 & 6.351 & 0.269 \\
\hline The deviation & $13.42 \%$ & $74.17 \%$ & $2.68 \%$ & $32.33 \%$ & $94.14 \%$ & $91.79 \%$ & $18.41 \%$ & $99.78 \%$ & $0.16 \%$ & $51.02 \%$ & $16.22 \%$ & $50.70 \%$ \\
\hline $10 \mathrm{~g} / 5 \mathrm{~g}$ & 1.62 & 0.68 & 1.25 & 2.53 & 3.09 & 1.19 & 1.17 & 38.94 & 1.37 & 0.38 & 1.72 & 0.61 \\
\hline \multicolumn{13}{|c|}{$\begin{array}{l}\text { Detection result: } \\
\text { 1. Whether it is microwave ash } 5 \mathrm{~g} \text { or } 10 \mathrm{~g} \text { crude oil sample, the deviation of the data of the two Detection results of many metal elements is relatively large, up } \\
\text { to } 99.78 \% \text {, the sample detection is not parallel. }\end{array}$} \\
\hline
\end{tabular}

Table 4. Effect of Different Acids on the Dissolution of Metallic Elements in The Ash.

\begin{tabular}{|c|c|c|c|c|c|c|c|c|c|c|c|c|}
\hline different acids & $\begin{array}{l}\text { Cu 63 } \\
(\mathrm{ppb})\end{array}$ & $\begin{array}{l}\text { Sr } 88 \\
\text { (ppb) }\end{array}$ & $\begin{array}{l}\text { Bi } 209 \\
\text { (ppb) }\end{array}$ & $\begin{array}{l}\text { In } 115 \\
\text { (ppb) }\end{array}$ & $\begin{array}{l}\text { Li } 7 \\
\text { (ppb) }\end{array}$ & $\begin{array}{l}\text { Co } 59 \\
(\mathrm{ppb})\end{array}$ & $\begin{array}{l}\text { Ga } 69 \\
(\mathrm{ppb})\end{array}$ & $\begin{array}{l}\text { Mo } 98 \\
\text { (ppb) }\end{array}$ & $\begin{array}{l}\text { Cd } 111 \\
\text { (ppb) }\end{array}$ & $\begin{array}{l}\text { Ge } 74 \\
(p p b)\end{array}$ & $\begin{array}{l}\text { Cs } 133 \\
\text { (ppb) }\end{array}$ & $\begin{array}{l}\text { Rb 85 } \\
(\mathrm{ppb})\end{array}$ \\
\hline $\mathrm{HNO}_{3}, 5 \mathrm{ml}$ & 10.553 & 5.972 & 0.125 & 0.039 & 16.142 & 1.117 & 1.116 & 0.682 & 0.246 & 0.046 & 0.015 & 0.140 \\
\hline Aqua regia, $4 \mathrm{ml}$ & 10.558 & 5.857 & 0.167 & 0.051 & 16.281 & 2.570 & 0.916 & 0.861 & 0.200 & 0.068 & 0.015 & 0.120 \\
\hline
\end{tabular}

Table 5. Recovery Rate of Metal after Adding Standard in Crude Oil Samples.

\begin{tabular}{|c|c|c|c|c|c|c|c|c|c|c|c|}
\hline Method & $\begin{array}{l}\text { Au } 197 \\
\text { (ppb) }\end{array}$ & $\begin{array}{l}\text { Hf } 180 \\
\text { (ppb) }\end{array}$ & $\begin{array}{l}\text { Ir } 193 \\
\text { (ppb) }\end{array}$ & $\begin{array}{l}\text { Pd } 106 \\
(\mathrm{ppb})\end{array}$ & $\begin{array}{l}\text { Pt } 195 \\
\text { (ppb) }\end{array}$ & $\begin{array}{l}\text { Rh } 103 \\
\text { (ppb) }\end{array}$ & $\begin{array}{l}\text { Ru } 102 \\
\text { (ppb) }\end{array}$ & $\begin{array}{l}\text { Sb 121 } \\
\text { (ppb) }\end{array}$ & $\begin{array}{l}\text { Sn } 118 \\
\text { (ppb) }\end{array}$ & $\begin{array}{l}\text { Te } 130 \\
\text { (ppb) }\end{array}$ & $\begin{array}{l}\text { Ni } 60 \\
(\mathrm{ppb})\end{array}$ \\
\hline Sample & 0.058 & 0.027 & 0.014 & 0.012 & 0.013 & 0.011 & 0.010 & 1.069 & 0.790 & 0.032 & 38.161 \\
\hline Add standard & 20.000 & 10.000 & 10.000 & 10.000 & 10.000 & 10.000 & 10.000 & 110.00 & 20.000 & 10.000 & 100.00 \\
\hline 5mlHNO3 Dissolution & 12.804 & 11.574 & 9.772 & 6.171 & 7.720 & 6.156 & 8.170 & 79.400 & 14.124 & 8.504 & 122.63 \\
\hline Recovery & $63.73 \%$ & $115.47 \%$ & $97.58 \%$ & $61.59 \%$ & $77.07 \%$ & $61.45 \%$ & $81.60 \%$ & $71.21 \%$ & $66.67 \%$ & $84.72 \%$ & $84.47 \%$ \\
\hline Aqua regia, $4 \mathrm{ml}$ dissolution & 20.600 & 8.940 & 7.789 & 9.388 & 6.777 & 6.810 & 7.020 & 96.546 & 13.405 & 9.216 & 97.497 \\
\hline Recovery & $102.71 \%$ & $89.13 \%$ & $77.75 \%$ & $93.76 \%$ & $67.64 \%$ & $67.99 \%$ & $70.10 \%$ & $86.80 \%$ & $63.08 \%$ & $91.84 \%$ & $59.34 \%$ \\
\hline
\end{tabular}

\subsubsection{Experimental Results of Microwave Digestion}

The samples of different quality of crude oil are placed in different digestion high-pressure tank, adding strong oxidizing acid such as nitric acid, these digestion high-pressure tank are put into the Microwave digestion apparatus, different microwave power, different digestion temperature and different time length are selected for digestion, add the standard substance and the crude oil to be digested together, the content of metal elements are detected by ICP-MS after constant volume of dilute nitric acid. The detection results under optimal conditions, shown in Table 6, Table 7, Table 8, Table 9, Table 10 and Table 11. 
Table 6. Detection Result of Parallel Sample.

\begin{tabular}{|c|c|c|c|c|c|c|c|c|c|c|c|c|c|}
\hline Sample & $\begin{array}{l}\text { V 51 } \\
\text { (ppb) }\end{array}$ & $\begin{array}{l}\text { In } 115 \\
\text { (ppb) }\end{array}$ & $\begin{array}{l}\mathbf{L i} 7 \\
\text { (ppb) }\end{array}$ & $\begin{array}{l}\text { La } 139 \\
\text { (ppb) }\end{array}$ & $\begin{array}{l}\text { Co 59 } \\
\text { (ppb) }\end{array}$ & $\begin{array}{l}\text { Ga 69 } \\
\text { (ppb) }\end{array}$ & $\begin{array}{l}\text { Mo 98 } \\
\text { (ppb) }\end{array}$ & $\begin{array}{l}\text { Cd } 111 \\
\text { (ppb) }\end{array}$ & $\begin{array}{l}\text { Ge 74 } \\
\text { (ppb) }\end{array}$ & $\begin{array}{l}\text { Cs 133 } \\
\text { (ppb) }\end{array}$ & $\begin{array}{l}\text { Rb 85 } \\
\text { (ppb) }\end{array}$ & $\begin{array}{l}\text { Re } 187 \\
\text { (ppb) }\end{array}$ & $\begin{array}{l}\text { Be } 9 \\
\text { (ppb) }\end{array}$ \\
\hline NO.1 & 21.589 & 19.341 & 22.547 & 18.593 & 20.995 & 33.092 & 21.041 & 21.988 & 0.086 & 0.132 & 1.314 & 0.044 & 0.051 \\
\hline NO.1 & 21.386 & 19.392 & 24.014 & 18.187 & 21.446 & 32.295 & 21.254 & 21.626 & 0.078 & 0.121 & 1.196 & 0.038 & 0.046 \\
\hline The deviation & $0.47 \%$ & $0.13 \%$ & $3.15 \%$ & $1.10 \%$ & $1.06 \%$ & $1.22 \%$ & $0.50 \%$ & $0.83 \%$ & $4.88 \%$ & $4.35 \%$ & $4.70 \%$ & $7.32 \%$ & $5.15 \%$ \\
\hline NO. 2 & 1.26 & 0.008 & 0.727 & 0.363 & 0.571 & 17.395 & 0.587 & 0.12 & 0.029 & 0.09 & 0.965 & 0.011 & 0.031 \\
\hline NO. 2 & 1.252 & 0.009 & 0.857 & 0.329 & 0.62 & 18.57 & 0.607 & 0.107 & 0.031 & 0.097 & 1.047 & 0.01 & 0.032 \\
\hline The deviation & $0.32 \%$ & $5.88 \%$ & $8.21 \%$ & $4.91 \%$ & $4.11 \%$ & $3.27 \%$ & $1.68 \%$ & $5.73 \%$ & $3.33 \%$ & $3.74 \%$ & $4.08 \%$ & $4.76 \%$ & $1.59 \%$ \\
\hline
\end{tabular}

Table 7. Effect of Different Acids On The Digestion of Metallic Elements In The Crude Oil, Test 1.

\begin{tabular}{|c|c|c|c|c|c|c|c|c|c|}
\hline Different acids & $\begin{array}{l}\text { Au } 197 \\
\text { (ppb) }\end{array}$ & $\begin{array}{l}\text { Hf } 180 \\
(p p b)\end{array}$ & $\begin{array}{l}\text { Ir } 193 \\
(\mathrm{ppb})\end{array}$ & $\begin{array}{l}\text { Pd } 106 \\
\text { (ppb) }\end{array}$ & $\begin{array}{l}\text { Pt } 195 \\
\text { (ppb) }\end{array}$ & $\begin{array}{l}\text { Rh } 103 \\
\text { (ppb) }\end{array}$ & $\begin{array}{l}\text { Ru } 102 \\
\text { (ppb) }\end{array}$ & $\begin{array}{l}\text { Sb 121 } \\
\text { (ppb) }\end{array}$ & $\begin{array}{l}\text { Te } 130 \\
\text { (ppb) }\end{array}$ \\
\hline $8 \mathrm{ml} \mathrm{HNO}_{3}+0.5 \mathrm{~g}$ crude oil & 0.323 & 0.376 & 0.249 & 0.411 & 0.236 & 0.293 & 0.310 & 0.549 & 0.273 \\
\hline $8 \mathrm{ml} \mathrm{HNO}+1 \mathrm{ml} \mathrm{H}_{2} \mathrm{O}_{2}+0.5 \mathrm{~g}$ crude oil & 0.354 & 0.327 & 0.241 & 0.323 & 0.224 & 0.282 & 0.295 & 0.479 & 0.273 \\
\hline $8 \mathrm{ml} \mathrm{HNO}_{3}+0.5 \mathrm{~g}$ crude oil $+20 \mathrm{ppb}$ Noble metal & 19.286 & 27.612 & 24.093 & 22.177 & 22.051 & 27.144 & 27.916 & 23.724 & 22.446 \\
\hline $8 \mathrm{ml} \mathrm{HNO}+1 \mathrm{ml} \mathrm{H}_{2} \mathrm{O}_{2}+0.5 \mathrm{~g}$ crude oil $+20 \mathrm{ppb}$ Noble metal & 20.543 & 25.697 & 23.123 & 20.268 & 21.766 & 25.769 & 26.065 & 24.399 & 24.666 \\
\hline
\end{tabular}

Table 8. Effect of Different Acids On The Digestion of Metallic Elements In The Crude Oil, Test 2.

\begin{tabular}{|c|c|c|c|c|c|c|c|c|c|}
\hline Different acids & Au 197 (ppb) & $\begin{array}{l}\text { Sb 121 } \\
\text { (ppb) }\end{array}$ & $\begin{array}{l}\text { Pd } 106 \\
\text { (ppb) }\end{array}$ & $\begin{array}{l}\text { Ni } 60 \\
(p p b)\end{array}$ & $\begin{array}{l}\text { Cr } 52 \\
(\mathrm{ppb})\end{array}$ & $\begin{array}{l}\text { In } 115 \\
\text { (ppb) }\end{array}$ & $\begin{array}{l}\mathrm{Zr} 90 \\
(\mathrm{ppb})\end{array}$ & $\begin{array}{l}\text { Co } 59 \\
(p p b)\end{array}$ & $\begin{array}{l}\text { Mo 98 } \\
\text { (ppb) }\end{array}$ \\
\hline $8 \mathrm{ml} \mathrm{HNO}_{3}+1 \mathrm{ml} \mathrm{H}_{2} \mathrm{O}_{2}+0.5 \mathrm{~g}$ crude oil & 0.053 & 0.087 & 0.053 & 27.638 & 21.304 & 0.004 & 0.194 & 0.665 & 0.495 \\
\hline $8 \mathrm{ml} \mathrm{HNO}+1 \mathrm{ml} \mathrm{H}_{2} \mathrm{O}_{2}+0.5 \mathrm{~g}$ crude oil $+2 \mathrm{mlHCL}$ & 1.709 & 0.306 & 0.232 & 37.004 & 26.225 & 0.011 & 0.117 & 0.891 & 0.446 \\
\hline $8 \mathrm{mlHNO}_{3}+2 \mathrm{mlHCL}+1 \mathrm{mlH}_{2} \mathrm{O}_{2}$, blank & 3.486 & 3.861 & 0.785 & 6.415 & 21.146 & 0.004 & 0.265 & 0.068 & 0.225 \\
\hline
\end{tabular}

Detection result: After HCL entry, the detection result is high, and the blank value is also high. The blank value of some elements is higher than that of the sample detection. Therefore, in order to ensure the accuracy of the detection results, HCL cannot be added to the sample when digestion.

Table 9. Detection Result of Digesting Different Amount of Crude Oil.

\begin{tabular}{|c|c|c|c|c|c|c|c|c|c|c|c|}
\hline Different amount of crude oil & $\begin{array}{l}\text { Ni } 60 \\
\text { (ppb) }\end{array}$ & $\begin{array}{l}\text { Sr 88 } \\
\text { (ppb) }\end{array}$ & $\begin{array}{l}\text { V 51 } \\
\text { (ppb) }\end{array}$ & $\begin{array}{l}\text { Li } 7 \\
\text { (ppb) }\end{array}$ & $\begin{array}{l}\text { Zr 90 } \\
\text { (ppb) }\end{array}$ & $\begin{array}{l}\text { Co } 59 \\
\text { (ppb) }\end{array}$ & $\begin{array}{l}\text { Ga } 69 \\
\text { (ppb) }\end{array}$ & $\begin{array}{l}\text { Mo } 98 \\
\text { (ppb) }\end{array}$ & $\begin{array}{l}\text { Ge } 74 \\
(p p b)\end{array}$ & $\begin{array}{l}\text { Cs } 133 \\
\text { (ppb) }\end{array}$ & $\begin{array}{l}\text { Rb 85 } \\
\text { (ppb) }\end{array}$ \\
\hline $0.25 \mathrm{~g}$ crude oil & 13.224 & 1.643 & 0.644 & 0.313 & 0.1969 & 0.372 & 0.306 & 0.092 & 0.021 & 0.004 & 0.052 \\
\hline $0.50 \mathrm{~g}$ crude oil & 26.132 & 3.241 & 1.232 & 0.617 & 0.374 & 0.781 & 0.601 & 0.187 & 0.043 & 0.009 & 0.107 \\
\hline $1.00 \mathrm{~g}$ crude oil & 56.091 & 6.407 & 2.35 & 1.198 & 0.784 & 1.648 & 1.275 & 0.401 & 0.083 & 0.019 & 0.211 \\
\hline $0.50 \mathrm{~g}$ result $/ 0.25 \mathrm{~g}$ result & 1.98 & 1.97 & 1.91 & 1.97 & 1.90 & 2.10 & 1.96 & 2.03 & 2.05 & 2.25 & 2.06 \\
\hline $1.00 \mathrm{~g}$ result $/ 0.50 \mathrm{~g}$ result & 2.15 & 1.98 & 1.91 & 1.94 & 2.10 & 2.11 & 2.12 & 2.14 & 1.93 & 2.11 & 1.97 \\
\hline
\end{tabular}

Detection result: The amount of sample digestion is proportional to the detection results, indicating that the amount of sample digestion does not affect the detection results, and the uniformity of the crude oil samples is good.

Table 10. Recovery Rate of Metal After Adding Standard in Crude Oil Samples.

\begin{tabular}{|c|c|c|c|c|c|c|c|c|c|}
\hline Method & $\begin{array}{l}\text { Au } 197 \\
\text { (ppb) }\end{array}$ & $\begin{array}{l}\text { Hf } 180 \\
\text { (ppb) }\end{array}$ & $\begin{array}{l}\text { Ir } 193 \\
(\mathrm{ppb})\end{array}$ & $\begin{array}{l}\text { Pd } 106 \\
\text { (ppb) }\end{array}$ & $\begin{array}{l}\text { Pt } 195 \\
\text { (ppb) }\end{array}$ & $\begin{array}{l}\text { Rh } 103 \\
\text { (ppb) }\end{array}$ & $\begin{array}{l}\text { Ru } 102 \\
\text { (ppb) }\end{array}$ & $\begin{array}{l}\text { Sb 121 } \\
\text { (ppb) }\end{array}$ & $\begin{array}{l}\text { Te } 130 \\
\text { (ppb) }\end{array}$ \\
\hline $8 \mathrm{ml} \mathrm{HNO} 3+1 \mathrm{ml} \mathrm{H}_{2} \mathrm{O}_{2}+0.5 \mathrm{~g}$ crude oil & 0.254 & 0.327 & 0.241 & 0.323 & 0.224 & 0.282 & 0.295 & 0.479 & 0.273 \\
\hline $8 \mathrm{ml} \mathrm{HNO} 3+1 \mathrm{ml} \mathrm{H}_{2} \mathrm{O}_{2}+20 \mathrm{ppb}$ metal & 20.543 & 22.097 & 22.123 & 19.388 & 21.766 & 21.769 & 22.065 & 20.399 & 20.666 \\
\hline $8 \mathrm{ml} \mathrm{HNO} 3+1 \mathrm{ml} \mathrm{H}_{2} \mathrm{O}_{2}+4 \mathrm{ppb}$ metal & 4.383 & 4.345 & 4.601 & 4.499 & 4.254 & 4.519 & 4.277 & 4.312 & 4.142 \\
\hline Recovery rate, add $20 \mathrm{ppb}$ metal & $101.45 \%$ & $108.85 \%$ & $109.41 \%$ & $95.33 \%$ & $107.71 \%$ & $107.44 \%$ & $108.85 \%$ & $99.60 \%$ & $101.97 \%$ \\
\hline Recovery rate, add $4 \mathrm{ppb}$ metal & $103.23 \%$ & $100.45 \%$ & $109.00 \%$ & $104.40 \%$ & $100.75 \%$ & $105.93 \%$ & $99.55 \%$ & $95.83 \%$ & $96.73 \%$ \\
\hline
\end{tabular}

Detection result: The recovery rate of standard metal elements is very good, the lowest is $95.33 \%$, and the highest is $108.85 \%$. It shows that the detection results are accurate and reliable. 
Table 11. Reproducibility Detection Result.

\begin{tabular}{|c|c|c|c|c|c|c|c|c|c|c|}
\hline Different Identifier & $\begin{array}{l}\text { Au } 197 \\
\text { (ppb) }\end{array}$ & $\begin{array}{l}\text { Hf } 180 \\
\text { (ppb) }\end{array}$ & $\begin{array}{l}\text { Ir } 193 \\
\text { (ppb) }\end{array}$ & $\begin{array}{l}\text { Pd } 106 \\
\text { (ppb) }\end{array}$ & $\begin{array}{l}\text { Pt } 195 \\
\text { (ppb) }\end{array}$ & $\begin{array}{l}\text { Rh } 103 \\
\text { (ppb) }\end{array}$ & $\begin{array}{l}\text { Ru } 102 \\
\text { (ppb) }\end{array}$ & $\begin{array}{l}\text { Sb } 121 \\
\text { (ppb) }\end{array}$ & $\begin{array}{l}\text { Sn } 118 \\
(p p b)\end{array}$ & $\begin{array}{l}\text { Te } 130 \\
\text { (ppb) }\end{array}$ \\
\hline Sample 1, Identifier 1 & 0.323 & 0.376 & 0.249 & 0.411 & 0.236 & 0.293 & 0.310 & 0.549 & 1.691 & 0.273 \\
\hline Sample 1, Identifier 2 & 0.285 & 0.447 & 0.283 & 0.420 & 0.259 & 0.304 & 0.314 & 0.649 & 1.424 & 0.299 \\
\hline Sample 2, Identifier 1 & 19.286 & 27.612 & 24.093 & 22.177 & 22.051 & 27.144 & 27.916 & 23.724 & 28.535 & 22.446 \\
\hline Sample2, Identifier 1 & 20.096 & 30.558 & 24.944 & 20.972 & 22.693 & 25.711 & 26.413 & 23.290 & 27.862 & 22.172 \\
\hline Sample 1 , The deviation & $6.25 \%$ & $8.63 \%$ & $6.39 \%$ & $1.08 \%$ & $4.65 \%$ & $1.84 \%$ & $0.64 \%$ & $8.35 \%$ & $8.57 \%$ & $4.55 \%$ \\
\hline
\end{tabular}

Detection result: Detection results of different Identifier under the same condition, the reproducibility is very good, the maximum deviation is $8.63 \%$, indicating that the detection method is reliable.

\subsubsection{Detection Conclusion}

The crude oil samples are treated by microwave ashing and microwave digestion. The conclusion is that the microwave digestion method is very effective for the treatment of crude oil samples, and the effect of microwave ashing is very poor.

\section{Prospect of Utilization of Metal Resources in Crude Oil}

Crude oil contains a variety of metal resources in China. For example, Shengli Oil Field has detected high abundance of rare precious metals such as gold, silver and platinum in heavy oil, The average gold content is 0.977 ppm, and the highest content is $2.30 \mathrm{ppm}$. 63 kinds of metals are detected in the crude oil in the Toutai Oil Field. The metals are classified as follows, as shown in Table 12 .

Table 12. The Content of Metal in Toutai Oil Field.

\begin{tabular}{llllll}
\hline Content & Noble metals & $\begin{array}{l}\text { Rare earth } \\
\text { metals }\end{array}$ & $\begin{array}{l}\text { Rare light } \\
\text { metals }\end{array}$ & $\begin{array}{l}\text { Rare scattered } \\
\text { metals }\end{array}$ & $\begin{array}{l}\text { Rare refractory } \\
\text { metals }\end{array}$ \\
\hline The content of metal, $\mathrm{ug} / \mathrm{kg}$ & 23.14 & 62.61 & 78.4 & 96.17 & 290.47 \\
Total metal content, $\%$ & 0.044 & 0.118 & 0.148 & 0.181 & 52472 \\
metal
\end{tabular}

The rare metals are essential metals for the development of atomic energy, aviation and space, national defense construction, electronic computer, high point scientific instruments and so on. Although the resources of rare metals are abundant in China, the reserves of tungsten, indium and rare earth are ranked first in the world, and production also accounts for $80 \%$ of the total output of the world, but for a long time, china supplies $90 \%$ of the world's rare metals at a relatively low price, the reserves of rare metal resources in China are declining at an alarming rate. According to the statistics of the Ministry of Land and Resources, 5 years from 2005 to 2010, China's rare earth reserves have decreased by $37 \%$. By 2020, only 6 of the 45 major minerals could meet the needs of China.

The research on the prospect of comprehensive utilization of rare metals in crude oil is late in China. At present, due to technical reasons, the recovery and utilization of rare metals in crude oil cannot be realized. Although the content of rare metals in crude oil is very low, such as Canada, Venezuela, the United States and other countries, a large number of rare metals have been extracted, which provides valuable reference for extracting rare metals from Chinese crude oil.

In 2016, the production of crude oil in China was 199 million 680 thousand tons, the number of imports was 381 million 10 thousand tons, and the processing volume of crude oil was 541 million 10 thousand tons. There is a large amount of metal in the crude oil, therefore, with the research and development of the extraction of metal from crude oil, the extraction of metal from crude oil has a broad prospect in
China, It will also provide a useful supply of rare metal resources to meet the demand for rare metal resources.

\section{Conclusion}

In this paper, the detection technology of 63 metal elements in crude oil is established. The crude oil samples are processed by microwave digestion, the content of metal elements are detected by ICP-MS. The maximum deviation of the parallel sample detection is $8.21 \%$, the maximum deviation of the reproducibility detection is $8.63 \%$, and the recovery rate of the standard metal elements is $95.33 \%-108.85 \%$.

Through rvey come to know, many countries have industrialized from crude oil to extract valuable metal elements, but this work has not yet been carried out in China. The determinations of the crude oil of Toutai Oil Field of China, there are rich rare metal elements in the crude oil. Accordingly, the extraction of rare metal elements from crude oil, has a broad prospect in China.

\section{References}

[1] Gao Han, Ma Bo. Research Progress of Nickel and Vanadium in Petroleum. Contemporary Chemical Industry, 2007, 36 (6):574-576.

[2] Hu Chengming. Extraction of Metal from Crude Oil. World Science, 1988 (2):49-54. 
[3] Xi Yin. Production Technology of Vanadium from Petroleum Residue in Foreign Countries. World Nonferrous Metals, 2001 (5):36-40

[4] Ma Liangbang, Ge Ying. Determination of Trace Metal Elements in Solid Bitumen with Microwave Digestion by Inductively Coupled Plasma-Atomic Emission Spectrometry, Rock and Mineral Analysis, 2013, 32 (3):441-444.

[5] Shao Min, Yao Zhongwei. Study on Separation and Enrichment in the Analysis of Platinum Group Elements. Western Resources, 2015 (2):120-122.

[6] Lu Bin. Determination of Metal Elements in Crude Oil and Residuum by Direct Injection of ICP-AES Inductively Coupled Plasma Emission Spectrometry Oil. Journal of Anqing College (Natural Science Edition), 2009, 15 (2):61-66.

[7] Li Jingxi, Chen Farong. Determination of Trace Metal Elements in Different Crude Oils and Their Cluster Analysis. Journal of Instrumental Analysis, 2010, 29 (6):558-563.

[8] Zhao Zengyi. Distribution Characteristics of Trace Elements in Crude Oil in Junggar Basin and Its Application. Exploration and Development of Natural gas, 2007, 30 (2):30-33.

[9] Tang Xiaohua. The Study on the Characteristics of Nickel and Vanadium in Blend Crude Oil. China Academic Journal Electronic Magazine, 2016 (2):41-45.
[10] Jin Dawei. New Technology for Detecting Trace Metal Elements in Crude Oil (ICP-AES) and Its Application. West-China Exploration Engineering, 2016 (5):57-63.

[11] Suo Jinling. Determination of Metal Elements in Pipeline Transportation Crude Oil by Crucible Ashing and ICP-AES. Petroleum Processing and Petrochemicals, 2013, 44 (4): 100 104.

[12] Qiu Xingquan, Wu Xiaoyan. Analyzation of Metal Ion Interference in Determination of Total Chromium in Water by Flame Atomic Absorption Spectrometry. Guangdong Chemical Industry, 2017, 44 (349):272-275.

\section{Biography}

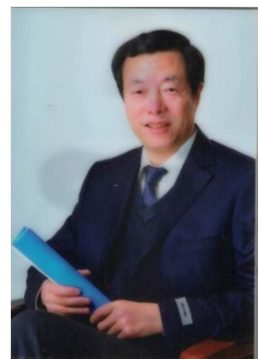

Bai Fengyou (1966-), male, senior engineer, mainly engaged in the study of oil field chemistry. 